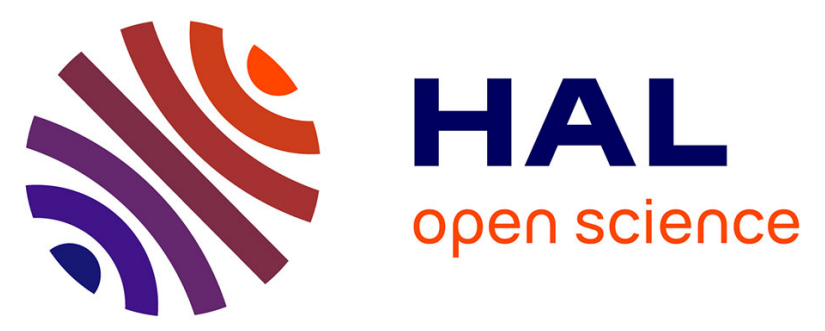

\title{
Development and sequels of intestinal inflammation in nematode-infected rats: role of mast cells and capsaicin-sensitive afferents
}

Jérôme Gay-Quéheillard, Jean Fioramonti, Rafael Garcia Villar, Lionel Bueno

\section{- To cite this version:}

Jérôme Gay-Quéheillard, Jean Fioramonti, Rafael Garcia Villar, Lionel Bueno. Development and sequels of intestinal inflammation in nematode-infected rats: role of mast cells and capsaicin-sensitive afferents. Neuroimmunomodulation, 2000, 8, pp.171-178. hal-02693684

\section{HAL Id: hal-02693684 \\ https://hal.inrae.fr/hal-02693684}

Submitted on 1 Jun 2020

HAL is a multi-disciplinary open access archive for the deposit and dissemination of scientific research documents, whether they are published or not. The documents may come from teaching and research institutions in France or abroad, or from public or private research centers.
L'archive ouverte pluridisciplinaire HAL, est destinée au dépôt et à la diffusion de documents scientifiques de niveau recherche, publiés ou non, émanant des établissements d'enseignement et de recherche français ou étrangers, des laboratoires publics ou privés.

\section{다(1)(2)}

Distributed under a Creative Commons Attribution - ShareAlikel 4.0 International 


\title{
Development and Sequels of Intestinal Inflammation in Nematode-Infected Rats: Role of Mast Cells and Capsaicin-Sensitive Afferents
}

\author{
Jerome Gay Jean Fioramonti Rafael Garcia-Villar Lionel Bueno \\ Neuro-Gastroenterology and Nutrition Unit, Institut National de la Recherche Agronomique, Toulouse, France
}

\section{Key Words}

Mast celis - Sensory neurons · Inflammation - Nematode infection

\begin{abstract}
Objectives: To determine whether intestinal mast cells and capsaicin-sensitive afferent nerves are involved in the development and sequels of Nippostrongylus brasim liensis-induced intestinal inflammation in rats. Methods: Two series of experiments were performed. In the first series, six groups of 8 rats were used to study the effects of mast cell stabilization by ketotifen. In the second series, six groups of 6 rats were used to study the effects of gut extrinsic sensory neuron depletion by capsaicin. For each series, four groups of rats were infected with N. brasiliensis and two groups were not infected. Results: Infection with $N$. brasiliensis resulted in an increase of myeloperoxidase (MPO) activity and mast cell numbers at day 12 postinfection; MPO returned to preinfection levels by day 35 while mast cell numbers remained elevated at that time. In ketotifen-treated infected rats, the increase of MPO at day 12 was less pronounced, but MPO activity remained elevated and mast cell numbers were increased at day 35 . In capsaicintreated infected rats, the MPO increase at day 12 was augmented, and MPO was still not returned to preinfection values by day 35 ; in contrast, the increase of mast cell numbers at days 12 and 35 was not modified by afferent nerve depletion. Conclusion: Mast cell stabiliza-
\end{abstract}

tion decreased jejunal inflammation during the acute stage (day 12), but prolonged the inflammatory process until at least day 35 postinfection. The data also con. firmed the protective role of gut extrinsic sensory neurons against intestinal inflammation in a model of nematode infection and revealed that these afferent nerves do not seem crucial for the development of nematodeinduced hypermastocytosis.

Copyright 2001 S. Karger AG, Basel

\section{Introduction}

Both sensory neurons and mast cells have been found involved in intestinal inflammatory processes. Thus, while afferent nerves exert a protective role upon intestinal tissues [1-3], mast cells are generally implicated in the development of the inflammatory process [4, 51. However, these roles are inferred from data obtained at a given time in experimental models of intestinal inflammation in animals. In contrast, inflammatory bowel disease (IBD) in humans is a chronic disease with intermingled periods of remission and relapse; the role of sensory neurons in the development of IBD has never been investigated.

The development of the intestinal inflammation induced by the nematode Nippostrongylus brasiliensis is well documented. $N$. brasiliensis induces an acute inflammation in the jejunum whose intensity peaks $12-14$ days after infection [6]. This inflammation is characterized by mucosal lesions that consist of villus atrophy and crypt

\footnotetext{
Dr. Jean Fioramont

INRA, NGN Unit

BP 3

F-31931 Toulouse (France)

Tel. +335612851 49, Fax +335612853 97, E-Mail fiforamo@toulouse.inta.fr
} 
a

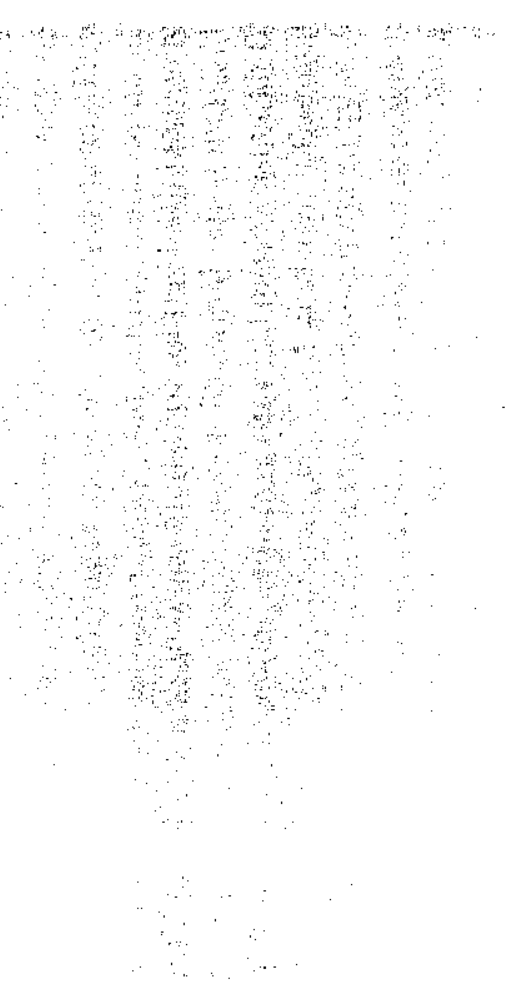


hyperplasia associated with mast cell activation and leukotriene generation [5-7]. Thirty days after infection, jejunal inflammation has resoived but mucosal mast cell hyperplasia and a profound enteric nerve remodeling persist for several weeks $[8,9]$.

Thus, a role of mast cells and their mediators has been found in some animal models of experimental inflammation $[10-13]$, whereas some studies have shown that mast ceils may not be essential in other experimental models such as trintrobenzene sulfonic acid (TNBS)- or dextran sodium sulphate (DSS) induced colitis in mice [14 15$] \mathrm{I}$ man, however, a greater number of intestinal mast cells has been reported in IBD patients in comparison with healthy subjects $[6,17]$ and mast cells may play a functional role in the inflammatory process of IBD [17] and its associated alterations of intestinal ion transport [16]. Several factors have been shown to promote and stimulate the development of mast cell hyperplasia such as $T$ cells [18], stem cell factor secreted by fibroblasts and other stromal cells, epithelial and endothelial cells $[19]$ interleukin-3 (iL-3), IL-4 and IL 10 produced by $\mathrm{T}$ cells and mast ells $[20,21]$.

The nervous system may also play a trophic role in the development of mast cells. Thus, truncal vagotomy or destruction of sensory afferent nerves by neonatal capsaicin significantly reduces the population of jejunal mucosal mast cells in rats [22]. This is anatomically supported by the close apposition between mast cells and sensory nerve fibers found both in normal and nematode-infected rats $[8,23,24]$. In addition, the number of jejunal mast cells in close association with neural processes is increased by $60 \%$ after $N$. brasiliensis infection in the rat [25], suggesting a dynamic interplay between the immune and nervous systems during inflammatory episodes in the gut.

The aim of this study, therefore, was to investigate the involvement of both resident mast cells and capsaicinsensitive afferent nerves in the modulation of the intensity and development of jejunal inflammation and mast cell hyperplasia in rats infected with the nematode $N$. brasiliensis.

\section{Material and Methods}

\section{Animals and Nematode Infection}

Male Wistar rats weighing 250-300 g were used for these experiments. Animals were housed in polypropylene cages with a standard diet (A04, Usine d'Alimentation Rationnelle, Epinay-sur-Orge; France) and tap water provided ad libitum. Experiments were conducted in control and $N$. brasiliensis-infected rats. Infection was achieved via subcutaneous (s.c.) injection of 2,500 third-stage (L3) infective larvae of $N$. brasiliensis in $0.5 \mathrm{ml}$ saline ( $\mathrm{NaCl} 0.9 \%)$ into the fiank of the rats (day 0). Controis received a single s.c. injection of $0.5 \mathrm{ml}$ saline at day 0 . The dose and route of administration of infective larvae were consistent with previously described techniques $[26$, 27]:

\section{Myeloperoxidase Activity}

The activity of the enzyme myeloperoxidase (MPO), a granulocyte-associated enzyme mainly present in polymorphonuclear neutrophils, was determined in jejunal tissues according to Bradley et al. [28]. Fuil-thickness segments of jejunum ( $2 \mathrm{~cm}$ long) were suspended in potassium phosphate buffer $(50 \mathrm{mM}, \mathrm{pH} 6.0)$ and homogenized in ice using a Polytron ( $3 \times 10$ sat maximal speed setting). Three cycles of freezing and thawing were done. Suspensions were then centrifiged at $10,000 \mathrm{~g}$ for $15 \mathrm{~min}$ at $4 . \mathrm{C}$. Supernatants were discarded and pellets were resuspended in hexadecyl trimethylammonium bromide buffer $(0.5 \% \mathrm{~W} / \mathrm{V}$ in potassium phosphate buffer); a detergent inclucing a release of MPO from neutrophilis: These suspensions were soricated on ice and again centrifuged at $10,000 \mathrm{~g}$ for $15 \mathrm{~min}$ at $4^{\circ} \mathrm{C}$. Supernatants were then diluted in potassium phosphate buffer containing $0.67 \mathrm{mg} / \mathrm{ml}$ of - -dianisidine dihydrochloride and $0.0005 \%$ of hydrogen peroxide. MPO from human neutrophils (Sigma, St. Louis, Mo., USA; 0.1 U/100 $\mu 1$ ) was used as a standard. Changes in absorbance at $450 \mathrm{~nm}$ were recorded every 10 s over $2 \mathrm{~min}$ with a spectrophotometer (Uvikon 860, Kontron Instruments, St Quentin-en-Yvelines, France) Protein concentration: $(\mathrm{g} / \mathrm{ml}$ ) was determined by the modified method of Lowry (Detergent Compatible Assay, BioRad, Ivry-sur-Seine, France), and MPO activity was expressed as MPO units/gram protein, 1 MPO activity unit being defined as the quantity of MPO degrading $1 \mu \mathrm{mol}$ hydrogen peroxide $/ \mathrm{min} / \mathrm{ml}$ at $25^{\circ} \mathrm{C}$.

\section{Histology}

Full-thickness pieces of jejunum (1 cm long), collected $10 \mathrm{~cm}$ distal to the ligament of Treitz, were fixed in Carnoy's solution, cleared in toluene and embedded in paraffin blocks. Transverse sections ( 5 um thick) were stained with Alcian biue-safranin $O$ according to Roberts et al. [29], for identification of intestinal mast cells, both in the mucosa and submucosa. Three sections per animal and three views per section were examined in a blind fashion. Numbers of mast cells per square millimeter of jejunal mucosa and submucosa were determined with an image grabbing program (Neotech, Paris, France) and an image analysis software package (Optilab Pro, Graftek, Paris, France) running on an Apple Macintosh $7100 / 80$ (Cupertino, Calif., USA). Other slices (5 $\mu$ m thick) from each intestinal sam. ple, were stained with hemalum and eosin, and examined by light microscopy in a blinded manner for histological analysis.

\section{Quantification of Worms in the Small Intestine}

Eight groups of 4 rats were used for quantification of adult (L5) $N$. brasiliensis worms in the small intestine of infected rats. Four groups were treated with ketotifen and four groups with its vehicle as previously described. Rats were euthanized by cervical dislocation under anesthesia $4,7,12$ or 21 days after infection. The entire small intestine was removed and divided into five segments corresponding to duodenum, three identical segments of jejunum, and ileum. Each segment was cut longitudinally, attached with a cotton thread and placed in a plastic tube containing $30 \mathrm{ml}$ of $\mathrm{NaCl} 0.9 \%$. Tubes were then placed in water at $37^{\circ} \mathrm{C}$ for $2 \mathrm{~h}$. Worms were quantified at the bottom of the tubes (method adapted from D'Inca et al. [301). 
Experimental Procedures

Two series of experiments were undertaken, each using six groups of 8 or 6 rats, for the study of the effects of ketotifen and capsaicin, respectively. For both series, four groups of rats were infected with $N$. brasiliensis ('Nb' groups) and two groups were not infected ('controls'). Animals were sacrificed at the end of their respective treatment. For ketotifen studies, three groups (two $\mathrm{Nb}$, one control) received ketotifen (Sigma, $1 \mathrm{mg} / \mathrm{kg}$, orally, b.i.d.) from 4 days before to 12 (one $\mathrm{Nb}$ ) or 35 days (one $\mathrm{Nb}$ and controls) after infection ( $\mathrm{Nb}$ groups) or saline injection (control grotip). The three other groups received saline $(0.5 \mathrm{ml}$, orally, b.i.d.) instead of ketotifen for 12 (one $\mathrm{Nb}$ ) or 35 days (one $\mathrm{Nb}$ and controls). A previous study showed that ketotifen pretreatment of tats with $1 \mathrm{mg} / \mathrm{kg}$ twice daily for 4 days prevented the release of mast cell mediators [31]. We chose the same dose of ketotifen in our study $\mathrm{A}$ similar protocol was followed for capsaicin studies. Three groups (two Nb, one control) received capsaicin 1 week before infection (Nb groups) or saline injection (control group). Thus, increasing doses of capsaicin (Fluka Chemie, Buchs, Switzeriand), dissolved in $10 \%$ ethanol, $10 \%$ Tween $80,80 \% \mathrm{NaCl}$ (referred to as 'vehicle'), were Hinected scotwice daily for 4 days, to reach a total dose of $100 \mathrm{mg} / \mathrm{kg}$ according to the following schedule: 5,$5 ; 5,15 ; 15,15 ; 20,20 \mathrm{mg} / \mathrm{kg}$. Capsaicin was administered via the systemic route, as indicated by Holzer [32]. The effectiveness of capsaicin treatment was tested by means of the eye-wiping test, which consists of impaired chemosensitivity of comeal afferents to one drop of $1 \% \mathrm{NH}_{4} \mathrm{OH}$ instilled in to the eye [33]. The other three groups (two $\mathrm{Nb}$, one control) received the vehicle (0.5 ml, s.c., b.i.d.) instead of capsaicin.

\section{Data Analysis}

MPO activity, mast cell counts and worm counts were expressed as the mean \pm SEM for each group of rats. Statistical anaiysis was performed using analysis of variance (ANOVA) and the Tukey post hoc test. $p<0.05$ was considered statistically significant.

\section{Results}

\section{MPO Activity}

$N$. brasiliensis-infected rats treated with saline presented an acute jejunal inflammation at 12 days after infection, corresponding to an increase of MPO activity ( 380.0 \pm 55.3 vs. $54.7 \pm 14.1 \mathrm{MPO}$ units/g protein in controls), which returned to normal preinfection values by day 35 postinfection $(44.1 \pm 10.7 \mathrm{MPO}$ units/g protein) indicating that acute tissue inflammation had resolved. Ketotifen treatment reduced the increase of MPO activity at day 12 postinfection $(207.3 \pm 18.3 \mathrm{MPO}$ units/g protein) compared to that observed in saline-treated infected rats; however, MPO activity remained elevated at day 35 postinfection in ketotifen-treated infected rats $(298.8 \pm$ $40.9 \mathrm{MPO}$ units/g protein) indicating that jejunal inflammation persisted (fig. 1a). In control noninfected rats, ketotifen treatment for 35 days increased jejunal MPO

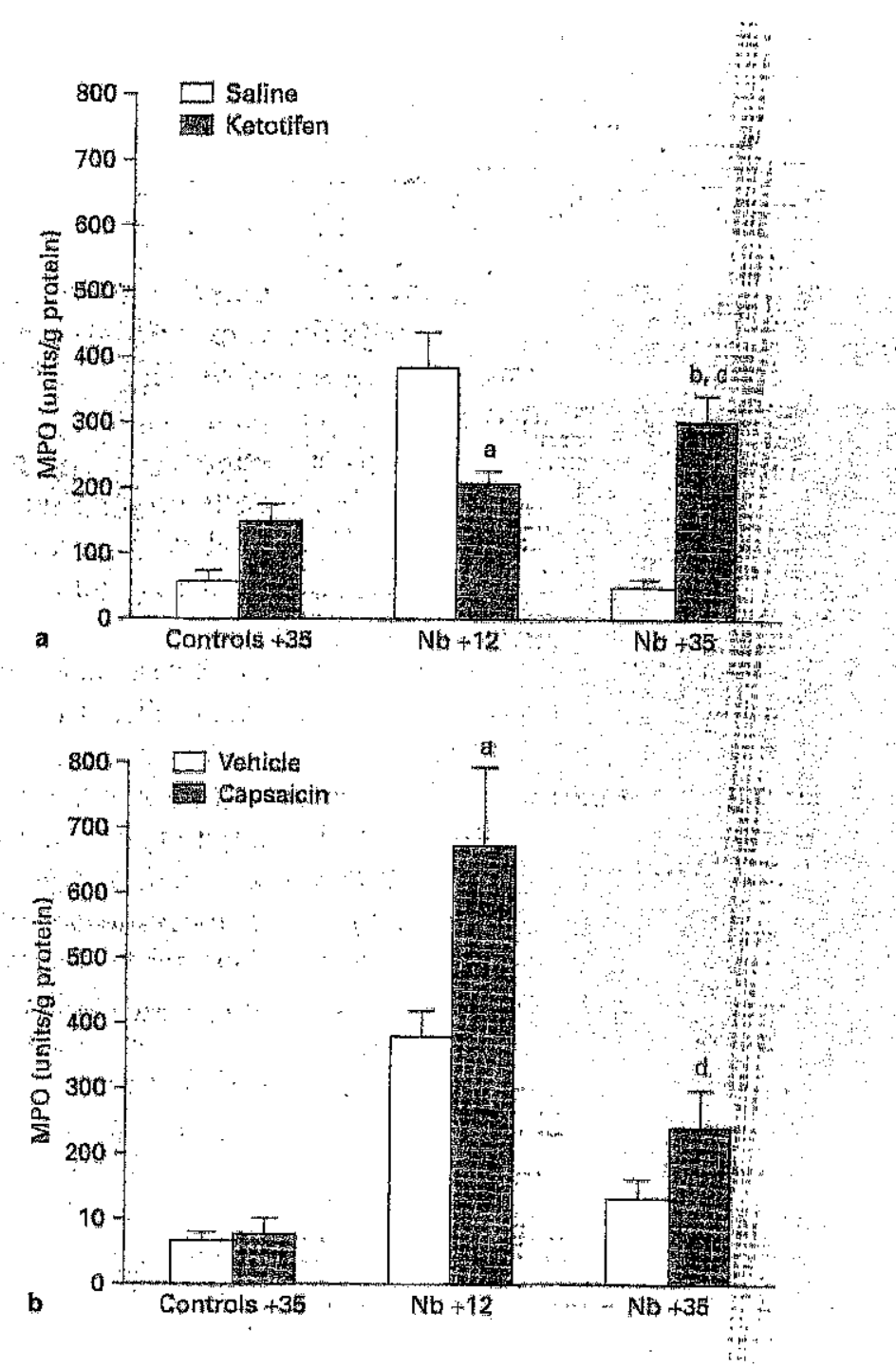

Fig. 1. Effects of ketotifen treatment (1 mg/kg/day, orally) or saline $(0.9 \% \mathrm{NaCl}, 0.5 \mathrm{mi} / \mathrm{day}$, orally) (a) and of pretreatment with capsaicin $(100 \mathrm{mg} / \mathrm{kg}, \mathrm{s.c}$.) or its vehicle (ethanol-Tween 80 -saline, $0.2 \mathrm{ml}$, s.c.) (b) on MPO activity in the jejunum of $N$. brasiliensis-infected rats (12 and 35 days postinfection) and controls ( 35 days). Values are means $\pm \operatorname{SEM}(n=6-8)$. $a^{\star} \mathrm{p}<0,05$ vs. saline-treated $\mathrm{Nb}$ (12 days); ${ }^{b} \mathrm{p}<0.05$ vs. saline-treated $\mathrm{Nb}$ ( 35 days); ${ }^{\mathrm{c}} \mathrm{p}<0.05$ vs. controls $(35$ days) treated with ketotifen. $\mathbf{b}^{\mathrm{a}} \mathrm{p}<0.05$ vs. vehicle-treated $\mathrm{Nb}(12$ days); ${ }^{\mathrm{d}} \mathrm{p}<0.05$ vs. capsaicin-treated controls (35 days).

activity but this increase did not reach statistical significance (fig. la).

In $N$. brasiliensis-infected rats treated with capsaicin vehicle, MPO activity leveis were similar to those described above in saline-treated rats (fig. 1b). $N$. brasiliensis-infected rats treated with capsaicin showed an increase 


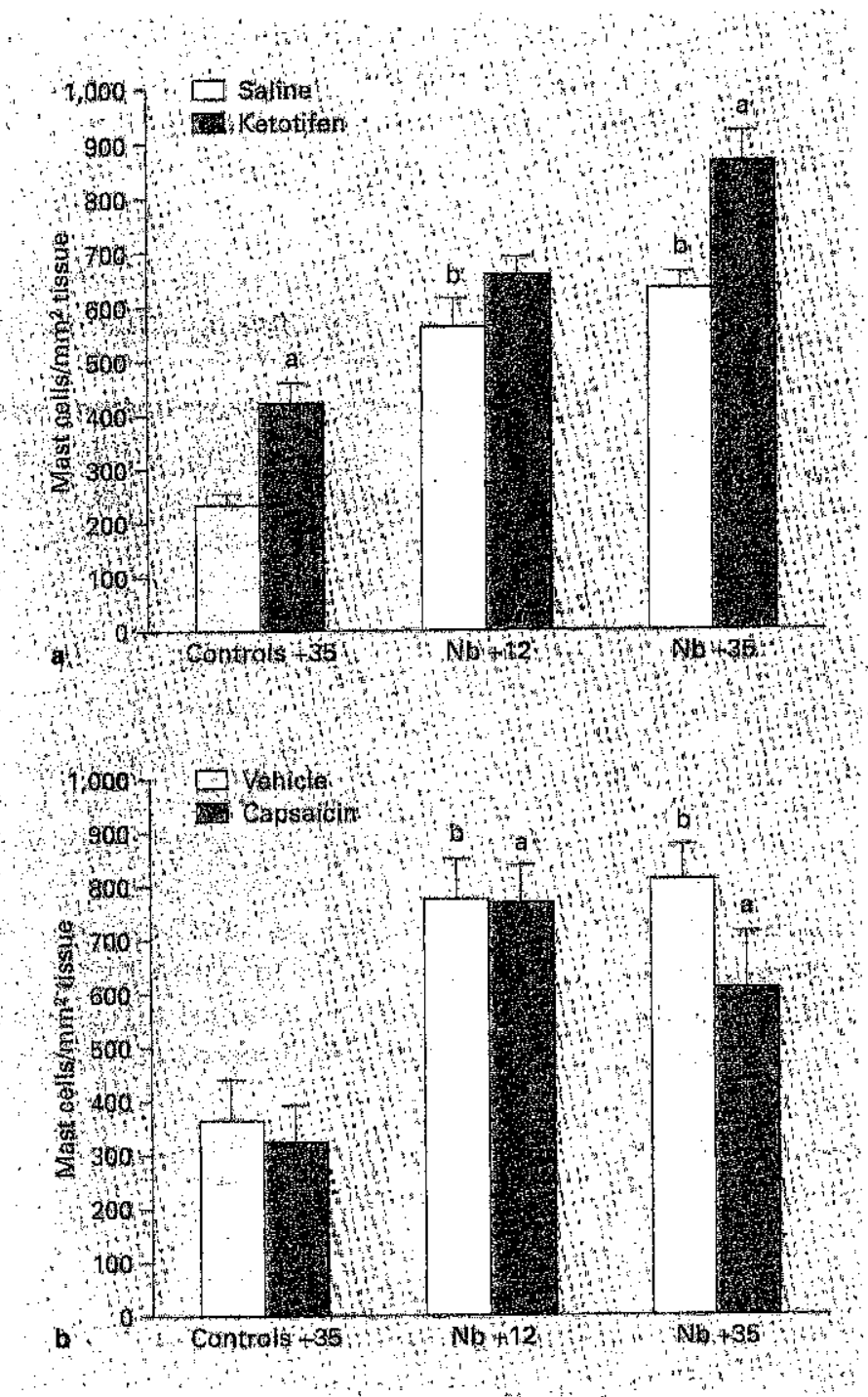

Fig. 2. Effects of ketotifen treatment (1 mg/ $\mathrm{kg} /$ day, orally) or saline $(0.9 \% \mathrm{NaCl}, 0.5 \mathrm{ml} / \mathrm{day}$, orally) (a) and of pretreatment with capsaicin $(100 \mathrm{mg} / \mathrm{kg}$, s.c.) or its vehicle (ethanol-Tween 80 -saline, $0.2 \mathrm{ml}$, s.c.) (b) on mast cell numbers in the jejunum of $N$. brasiliensism infected rats (12 and 35 days postinfection) and controls (35 days). Values are means $\pm \operatorname{SEM}(n=6 \sim 8)$, $\mathrm{a}^{\mathrm{a}} \mathrm{p}<0.05$ vs. their respective saline-treated group; ${ }^{b} \mathrm{p}<0.05$ vs. saline-treated controls (35 days). $\mathbf{b}^{\mathrm{a}} \mathrm{p}<0.05$ vs. capsaicin-treated controls ( 35 days); ${ }^{b} \mathrm{p}<0.05$ vs. vehicle-treated controls ( 35 days).

of MPO activity compared with vehicle-treated rats at day $12(667.1 \pm 121.5$ vs. $374.2 \pm 39.6 \mathrm{MPO}$ units/g protein, respectively, $\mathrm{p}<0.05)$ and at day $35(234.4 \pm 55.6$ vs. $123.6 \pm 30.7 \mathrm{MPO}$ units/g protein, respectively, $\mathrm{p}<$ 0.05 ) (fig. 1b). Capsaicin treatment had no effect on MPO activity in noninfected rats (fig. 1b).

\section{Histological Analysis}

At day 12, infected animals treated with saline were characterized by several morphological changes. A separation of the epithelium from the core of the lamina propria was consistently seen at the villus tips at this stage but not in control tissues. In most animals, a mucus cell hyperplasia and a thickness of the submucosa were observed: Some sections demonstrated regions where chains of enterocytes were in the process of getting detached. These animals were also characterized by moderate ulcerations, an important infiltration with numerous inflammatory cells and dilated blood vessels compared with controls and 35 days' postinfected animals. Ketotifen abolished the severity of the lesions at day 12 postinfection and only a few blood vessels were still dilated in three animäls.

In animals treated with the vehicle of capsaicin, 12 days postinfection, an infiltration of numerous inflammatory cells was observed but only two parameters, ulceration and infiltration, were augmented in most capsaicinpretreated rats, 12 days postinfection. In vehicle-pretreated rats, 35 days postinfection, all the parameters were normal and not different from controls: In capsaicinpretreated rats, 35 days postinfection, vascular dilation was still increased compared with vehicle-pretreated rats.

\section{Mast Cell Numbers}

In control noninfected rats, the number of stained mast cells in the jejunum was $239 \pm 19 / \mathrm{mm}^{2}$. This number was significantly increased $(\mathrm{p}<0.05)$ at day 35 in ketotifen-treated rats (fig. 2a) but not in capsaicin-treated rats (fig. 2b). In N. brasiliensis-infected rats, the number of mast cells was significantly increased $(p<0.05)$ on days 12 and 35 after infection (fig. 2a). Neither ketotifen nor capsaicin modify significantly $(p>0.05)$ the number of mast cells on the 12th day after infection. On the 35 th postinfection day, the number of mast cells was significantly $(p<0.05)$ higher in postinfected rats treated with ketotifen (fig. 2a) and not affected in capsaicin-treated rats (fig. 2b).

\section{Worm Counts}

Adult worms were found in the small intestine on days 4 and 7 after infection. They were localized mainly in the upper third of the jejunum and nearly absent in the duodenum and ileum. No worm was found in any of the intestinal segments studied at days 12 and 21 , suggesting that all worms were expelled from the small intestine by the 12th day after infection. Ketotifen treatment did not modify the number of worms at 4 and 7 days after infec- 
Table 1. Number of $N$. brasiliensis aduit worms at 4,7,12 and 21 days postinfection in intestinal segments of infected rats treated orally with ketotifen $(1 \mathrm{mg} / \mathrm{kg} /$ day $)$ or saline $(0.9 \% \mathrm{NaCl}, 0.5 \mathrm{ml} / \mathrm{day})$

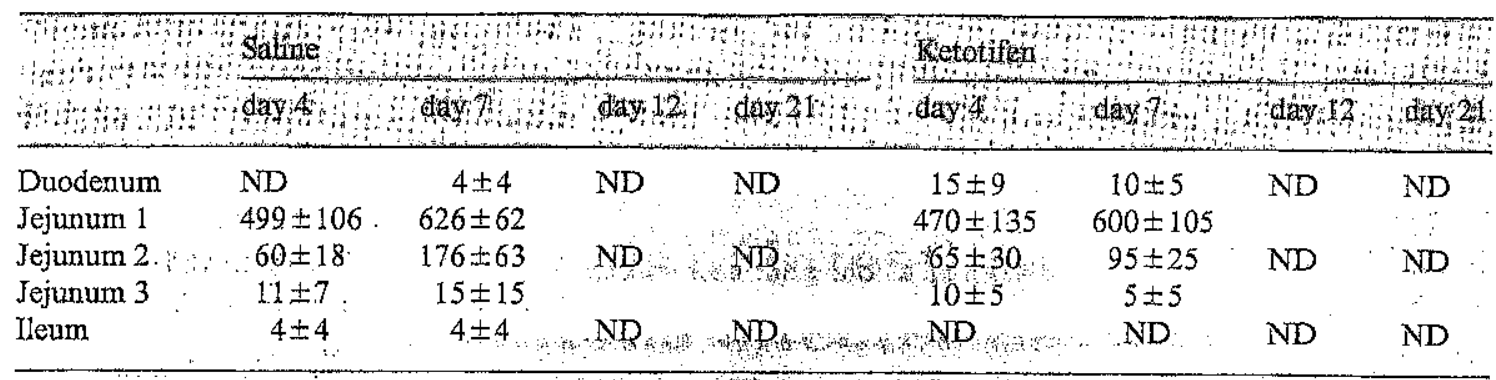

Values are means $+\operatorname{SEM}(\mathrm{n}=4): \mathrm{ND}=$ Not detected $\mathrm{F}$,

tion and did not affect the time of expulsion, i.e. absence of adult worms at 12 and 21 days (täble 1 ).

\section{Discussion}

This work was aimed at evaluating the role of mast cells and capsaicin-sensitive afferent neurons in the development and intensity of intestinal inflammation and mastocytosis induced by the nematode $N$ : brasiliensis in rats, an animal model which has been extensively used to study postinfective neuroimmune alterations in the digestive tract. To investigate the role of mast cells and afferent innervation in N. brasiliensis-induced inflammation and subsequent mast cell hyperplasia, we used ketotifen as a mast cell stabilizer and capsaicin for its ability to cause degeneration of primary afferent fibers.

Our results are consistent with a possible involvement of mast cells in the genesis and/or development of the N. brasiliensis-induced inflammatory reaction since MPO activity was less increased at 12 days after infection following treatment with the mast cell stabilizer ketotifen than in infected rats treated with saline. Histological analysis indicated a suppression by ketotifen of the lesions at day 12 postinfection since no infiltration or ulceration was observed compared with saline-treated rats. A role of mast cells in inflammatory processes has been described in several models of inflammation $[4,5]$. In addition, a protective effect of ketotifen in animal models of inflammation is well documented. Ketotifen prevents mucosal damage in experimental colitis induced by TNBS or acetic acid, an effect accompanied by a reduction in mucosal generation of platelet-activating factor $(\mathrm{PAF})$, prostaglandin $E_{2}$, thromboxane $B_{2}$, and leukotrienes $C_{4}$ and $B_{4}$; $\mathrm{MPO}$ activity was reduced as well [34]. In a model of jeju- nal inflammation induced by the sulfydryl blocker, iodoacetamide, and mimicking Crohn's disease, the protective effect of ketotifen indicates the contribution of proinflammatory mediators of mast cells to the pathogenesis of the damage [35]: In another model of gastric mucosal damage induced by ethanol; ketotifen prevented the lesions, probably through a reduction of mast cell mediator release [36]. A beneficial effect of ketotifen has also been reported in patients with eosinophilic gastroenteritis [37]. These results highlight the important role of mast cells and their mediators in the pathogenesis of gastric and intestinal inflammatory lesions. For example, in a rat model of colitis; local mast cell hyperplasia was observed and the antagonism of a major mast cell mediator, histamine, significantly reduces the severity of inflammation in this model [38]. In our study, we observed a ketotifen-induced reduction of the intensity of inflammation at 12 days after infection, but the inflammatory state was prolonged 35 days postinfection. We may then suppose that some mediators secreted by mast cells may favor repair mechaaisms during the late phase of inflammation. Another explanation for these results could be that, when the function of mast cells is dampened by ketotifen, other inflammatory cells may be recruited at the sites of inflammation to maintain the inflammatory state. Thus, mast cells could act not only as an active component of inflammation but also as an important modulator of inflammation in basal or stimulated states. Heyman et al. [39] demonstrated for the first time that ketotifen stimulated inducible nitric oxide synthase (iNOS) activity in rats and humans. Moreover, a recent study [40] suggests that leukocyte-derived iNOS ameliorates the early phase, but does not affect the chronic phase of TNBS-induced inflammation. Inhibition of NOS results in the activation of mast cells, increased epithelial permeability and leuko- 
cyte adhesion $[41,42]$. Consequently, our finding that ketotifen reduces or delays $N$. brasiliensis-induced inflammation 12 days after infection suggests that its antiinflammatory properties may be not only due to mast cell stabilization but also to NO generation. Moreover, ketotifen may act on inflammatory cells other than mast cells. For example, it may reduce the functions of mobility and phagocytosis of polymorphonuclear cells [43]; it may reduce the chemotaxis of neutrophils [44] or it may inhib. it theer metabolic responses [45]. It also inbibits leukotriene Ca release and PAF-induced chemotaxis of eosinophils [46]. Thus, the effect of ketotifen on inflammation may consist of a direct action on inflammatory cells or more tikely on mast cells by reducing the release of inflammatory and chemotactic factors.

The mastocytosis induced by ketotifen may serve as a compensatory mechanism to support mast cells which have undergone a complete or partial inhibition of their mediator release. Therefore, mast cell mediators such as cytokines may participate in the regulation of the number of mast cells in the tissues. It has been reported that mast cells differentiate and proliferate under the influence of an array of cytokines and growth factors, such as $\mathrm{LL}-3$, IL- 4 and $\mathrm{K}-10$ derived from $\mathrm{T}$ cells and possibly from mast cells $[20,21]$.

The present study also shows that ketotifen does not modify the apparent migration of larvae, their number and final localization. Thus, we can conclude that the inflammation observed 35 days after infection in ketotifen-treated animals is not due to a prolonged worm colonization induced by mast cell stabilization. Such a hypothesis arises from studies which have clearly established that mucosal mast cells are functionally active during spontaneous expulsion of intestinal nematodes in rats [47] and that $N$. brasiliensis infection is prolonged in genetically mast cell-deficient mice [48].

Our study also indicates that sensory denervation with capsaicin results in increased MPO activity during the acute phase of inflammation, 12 days postinfection. MPO is a granulocyte-associated enzyme, and a direct relationship between MPO activity measured in tissue samples and the number of neutrophils has been shown [28]. Consequently, a higher MPO activity in response to $N$. brasiliensis in capsaicin-treated rats supports an increased attraction and activity of neutrophils in jejunal mucosa although other cells such as eosinophils and macrophages contain low amounts of MPO. Moreover, the histological analysis showed an aggravation of ulceration and infiltration in most animals pretreated with capsaicin. Our data agree with the protective role of sensory neurons shown in
TNBS-induced models of colitis [1-3]. However, the role of sensory afferents on intestinal inflammation has been shown only with experimental models using TNBS, which is a Th1-predominant $T$ cell-mediated inflammation [49] while the inflammatory response induced by $N$. brasiliensis involved preferentially $\mathrm{Th} 2 \mathrm{~T}$ cell cytokines [50]. -Another important finding in this study concerns the prolonged inflammatory state 35 days postinfection in capsaicin-treated rats, which suggests that sensory innervam. tion might influence inflammation not only during the early phase but also at later stages in this model of nematode-induced inflammation. In contrast, Reinshagen et al." [1] indicated a role of sensory nerves during the early phase of colitis providing mucosal protection, while other factors were likely to prevail at later stages of chronic inflammation. However, it seems difficult to compare nematode-induced and chemically induced inflammations that differ markedly not only in the timing of cellular activation and cellular components involved in the development and repair, but also in the role of the resident microflora.

Pretreatment with capsaicin does not influence the number of jejunal mast cells in controls or the intensity of mastocytosis in the jejunum of rats at 12 and 35 days after nematode infection, suggesting that capsaicin-sensitive afferent nerves are not essential in the development of nematode-induced mast cell hyperplasia. However, it cannot be excluded that sensory denervation affects the number of nematodes present in the intestine. Nevertheless, it seems unlikely that the worm burden may be affected by capsaicin pretreatment. A previous study [51] has revealed that rats pretreated with systemic capsaicin did not display particular changes of motility patterns in comparison with the controls. Our data showing that capsaicin does not modify the number of jejunal mast cells in both controls and infected rats were not expected because mast cells and nerves are in intimate contact and a structural basis exists in the rat gastrointestinal tract for communication between the immune and nervous systems [8]. It has been shown that vagal afferent nerve fibers come in contact with mast cells in the rat small intestinal mucosa [24] and are responsible for the mucosal protection by sensory nerves [3]. Such a physiological communication is observed in a model of stress where activation of sensory nerves participates in stress-induced histamine release from mast cells in rats [52]. On the basis of these results we suggest a trophic influence of afferent nerves on mucosal mast cell maturation and proliferation. However, our results are in agreement with a study in which prior ablation of sensory afferent nerves by subcutaneous 
capsaicin administration 10 days before experiments did not significantly affect the numbers of mucosal mast cells within the gastric mucosa in either infected or noninfected rats [53]. On the other hand, neonatal treatment with capsaicin increased the number of rat mast cell protease II-immunoreactive mast cells in the dura mater [54]. It has also been reported that 3 weeks after vagotomy or 3 months after capsaicin administration, intestinal mucosal mast cells were almost $30 \%$ less numerous in capsalcintreated rat jejunum than in untreated controls [22].

In summary, our study suggests that mast cell stabiliza tion with ketotifen decreases jejunal inflammation during the acute stage (day 12) but prolonged the inflammatory state until at least day 35 postinfection in $N$. brasiliensisinfected rats. Our data also confirm the protective effect of intestinal sensory innervation against nematode-induced inflammation, whereas afferent nerves do not seem to be crucial in the development of intestinal mast cell hyperplasia:

\section{Acknowledgments}

The authors thank Dr. Charalabos Pothoulakis for his contribution to this paper, Colette Bétoulières and Lucien Ressayre for their skillfill technical assistance, INRA and Fondation pourla Recherche Medicale (FRM) for financial support.

\section{References}

1 Reinshagen M, Patel A, Sottili M, French S; Stemini C, Eysselein. VE: Action of sensory neurons in an experimental rat colitis model of injury and repair Am, J Physiol 1996;270: G79-G86.

2 Goso C, Evangelista $S$, Tramontara $M$, Marizini S, Blumberg PM, Szallasi A: Topical cap saicin administration protects against trinitro benzene sulfonic acidinduced coirtis in the rat. Eur J Pharmacol 1993;249 2*185-190

3 Mazelin $L$, Theodorou $V$, More $\$$, Fioramonti $\mathrm{J}$, Bueno L: Protective role of vagal afferents in experimentally-induced colitis in rats. ${ }^{\gamma}$ Auton Nerv Syst 1998;73:38-45.

4 Bienenstock J, Tomioka M, Matsuda $\mathrm{H}$, Stead RH, Quinonez $G$, Simon GT, Coughlin MD, Denburg JA: The role of mast cells in inflam. matory processes: Evidence for nerve/mast cell interaction. Int Arch Allergy Appl Immunol $1987 ; 82: 238-243$

5 Perdue MH, Ramage JK, Burget D, Marshall J, Masson S: Intestinal mucosal injury is associated with mast cell activation and leukotriene generation during Nippostrongylus-induced ixflammation in the rat. Dig Dis Sci 1989;34: 724-731.

6 Castex N, Fioramonti $J$, Ducos de Lahitte J, Luffau G, More J, Bueno L: Brain Fos expression and intestinal motor alterations during nematode-induced inflammation in the rat. Am J Physiol 1998;274:G210-G216.

7 Ramage JK, Hunt RH, Perdue MH: Changes in intestinal permeability and epithelial differentiation during inflammation in the rat. Gut $1988 ; 29: 57-61$.

8 Stead RH, Tomioka M, Quinonez G, Simon GT, Felten SY, Bienenstock J; Intestinal mucosal. mast ceils in normal and nematode-infected rat intestines are in intimate contact with peptidergic nerves. Proc Natl Acad Sci USA 1987; $84: 2975-2979$.
9 Arizono $\mathrm{N}$, Nakao $\mathrm{S}$ Kinetics and staining properties of mast cells proliferating in rat small intestine tunica muscularis and subserosa following infection with Nippostrongylus brasiliensis. APMIS 1988;96:964-970.

10 Galli SJ, Costa JJ Mast cell leukoyte cytokine cascades in allergic inflammation. Allergy $1995 ; 50: 851-862$

11 Konaka A; Nisbijum M,Tanaka A, Kunikata T, Kato S, Takeuchi K. Nitric oxide, superoxide radicals and mast cells in pathogenesis of indomethacin-induced small intestinal lesions in rats. J Physiol Pharmacol 1999;50 1:2,5-38.

12 luvone $T$, Van Den Bossche $R$, D'Acquisto $F$, Carnuccio R, Herman AG: Evidence that mast cell degramulation, histamine and tumour necrosis factor alpha release occur in LPS-induced plasma leakage in rat skin. Br J Pharmacol 1999;128:700-704.

13 Wersiil BK, Castagliuolo I, Pothoulakis C: Direct evidence of mast cell involvement in $\mathrm{Clos}$ tridium difficile toxin A-induced entertis in mice. Gastroenterology 1998;114:956-964.

14 Chin KW, Barrett KE: Mast cells are not essential to inflammation in murine model of colitis. Dig Dis Sci 1994;39:513-525.

15 Minocha A, Thomas C, Omar R: Lack of crucial role of mast cells in pathogenesis of experimental colitis in mice. Dig Dis Sci 1995;40: 1757-1762.

16 Crowe SE, Luthra GK, Perdue MH: Mast cetl mediated ion transport in intestine from patients with and without inflammatory bowel disease. Gut 1997;41:785-792.

17 Noite H, Spjeldnaes N, Kruse A, Windelborg B: Histamine release from gut mast cells from patients with inflammatory bowel diseases. Gut 1990;31:791-794.

18 Arizono N, Shiota T, Yamada M, Matsumoto Y, Yoshikawa $H$, Matsuda $S$, Tegoshi T: Bromodeoxyuridine labeling studies on the proliferation of intestinal mucosal mast cells in normal and athymic rats. APMIS 1990;98:369376.
19 Newlands GF, Miller HR, MacKellar A, Galli SJ: Stem cell factor contributes to intestinal mucosal mast cell hyperplasia in rats infected with Nippostrongylus brasiliensis or Trichinello spiralis, but anti-stem cell factor treatment decreases parasite egg production during $N$. bra siliensis infection. Blood 1995;86:1968-1976.

20 Thompson-Snipes L, Dhar V, Bond MW, Mosmann TR, Moore KW, Rennick DM: Initerleukin 10: A novel stimulatory factor for mast cells and their progenitors. J Exp Med 1991;173: $507-510$.

21 Schmitt E, Fassbender B, Beyreuther K, Spaeth E, Schwarzkopf R, Rude E: Characterization of a T ceil-derived lymphokine that acts synergistically with IL 3 on the growth of murine mast cells and is identical with IL 4. Immunobiology 1987; 174:406-419.

22. Gottwald T, Lhotak S, Stead RH: Effect of truncal vagotomy and capsaicin on mast cells and IgA-positive plasma cells in rat jejunal mucosa. Neurogastroenterol Motil 1997;9:25-32.

23 Stead RH: Innervation of mucosal immune cells in the gastrointestinal tract. Reg Immunol 1992;4:91-99.

24 Williams RM, Berthoud HR, Stead RY: Vagal afferent nerve fibres contact mast cells in rat small intestinal mucosa. Neuroimmunomodu lation 1997; 4:266-270.

25 Arizono N, Matsuda S, Hattori T, Kojima Y, Maeda T, Galli SY: Anatomical variation in toast cell nerve associations in the rat small intestine, heart, lung and skin. Siniliarities of distances between neural processes and mast cells, eosinophils, or plasma cells in the jejunal lamina propria. Lab Invest 1990;62:626 634 .

26 Masson SD, McKay DM, Stead RH, Agro A, Stanisz A, Perdue MH: Nippostrongylus brasiliensis infection evokes neuronal abnormalities and alterations in neurally regulated electrolyte transport in rat jejunum. Parasitology 1996; 113:173-182. 
27 McLean P, Picard C, Garcia-Villar R, More J, Fioramonti J, Bueno L: Effects of nematode infection on sensitivity to intestinal distension: Role of tachykinin NK2 receptors. Eur J Pharmacol 1997;337:279-282.

28 Bradley PP, Priebat DA, Christensen RD, Rothstein G: Measurement of cutaneous inflammation: Estimation of neutrophil content with an enzyme marker. I Invest Dermatol 1982;78:206-209.

29 Roberts ISD, Jones CJP, Stoddart RW, Letin histochemistry of the mast cell: Heterogeneity. of rodent and human mast cell populations.

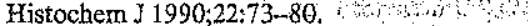

30 D'Inca R, Ernst P, Hunt RH, Perdue MHARole of $T$ lymphocytes in intestinal mueosal injary Inflammatory changes in athyunic ride trits. Dig Dis Sci 1992;37:33-39.

31 Pothoulakis $\mathrm{C}$, Karmeli F, Kelly CP, Eliakim $\mathrm{R}$, Joshi MA, O'Keane CJ, Castagliuoli Ir LaMont JT, Rachmilewitz D: Ketotifen inllibits Clostridium difficile toxin A-induced enteritis in rat ileum. Gastroenterology 1993;105:701707.

32 Holzer P: Capsaicin: Cellular targefs, mecha nisms of action, and selectivity for thin sensory neurons. Pharmacol Rev 1991;43:143 201

33 Gamse R: Capsaicin and nociception in the rat and mouse. Naunyn Schmiedebergs Atch Pliar macol 1982;320:205-216.

34 Eliakim R, Karmeli F, Okon E, Rachinilewitz $\mathrm{D}$ : Ketotifen effectively prevents mucosal dam age in experimental colitis. Gut 1992,331498 1503.

35 Rachmilewitz D, Okon E, Karmeli Fol Sulphydryl blocker induced small intestinal inflammation in rats: A new model mimicking Crohn's disease. Gut 1997;41:358-365.

36 Karneli $F$, Eliakim $R$, Okon E, Rachmilewitz $D$ : Gastric mucosal damage by ethanol is mediated by substance $P$ and prevented by ketotif en, a mast cell stabilizer. Gastroenterology 1991;100:1206-1216.
37 Melamed I, Feanny SJ, Sherman PM, Roifman CM: Benefit of ketotifen in patients with eosinophilic gastroenteritis. Am I Med 1991;90: 310-314.

38 Gelbmann CM, Barrett KE: Role of histamine in a rat model of colitis. Inflamm Res 1995;44 $386-392$.

39. Heyman SN, Karmeli $F$, Brezis $M$, Rachmilewitz D: The effect of ketotifen on nitric oxide synthase activity. Br J.Pharmacol 1997;120: is $545-1551$

40 McCafferty DM, Miampamba $M$, Sihota E Sharkey KA, Kubes P: Role of inducible nitric oxide synthase in trinitrobenzene sulphonic acid induced colitis in mice. Gut 1999;45:864 873.

41 Kubes P Kanwar S, Niu XF, Gaboury JP: Nitric oxidesynthesis inhibition induces leukocyte adhesion yia superoxide and mast cells. FASEB J $1993 ; 7 ; 1293-1299$.

42 Kanwar S, Wallace JL, Befus D, Kubes P: Nit ric oxide synthesis inhibition increases epithelial permeability via mast cells. Am I Physio 1994;266:G222-G229.

43 Gonzalez JA, Lorente F, Romo A, Muriel M, Palomero B, Salazar V: Action of ketotifen on different functions of neutrophil poiymorphonuclear cells. Allergol Immunopathol 1986;14 $215-220$

44 Shiratori $Y$; Takada H, Hai K, Kiriyama $H$ Mawet E, Komatsu Y, Niwa Y, Matsumura M, Shina $S$, Kawase $T$ : Effect of anti-allergic agents on chemotaxis of neutrophils by stimulation of chemotactic factor released from hepatocytes exposed to ethanol. Dig Dis Sci 1994; 39:1569-1575.

45 Taniguchi $\mathrm{K}$, Takanaka $\mathrm{K}$ : Inhibitions of metabolic responses of polymorphonuciear leukocytes by antiallergic drugs. J Pharmacobiodyn $1989 ; 12: 37-42$.
46 Nabe M, Miyagawa H, Agrawal DK, Sugiyama H, Townley RG: The effect of ketotifen on eosinophils as measured at LTC4 release and by chemotaxis. Allergy Proc 1991;12:267-271.

47 Woodbury RG, Míler HR, Huntley JF, Newlands GF, Palliser AC, Wakelin D: Mucosal mast cells are functionally active during spontaneous expulsion of intestinal nematode infecm tions in rat. Nature 1984;312:450-452.

48 Kojima S, Kitamura Y, Takatsu K: Prolonged infection of Nippostrongylus brasiliensis in ge: netically mast cell-depleted $W / W v$ mice . Im munol Lett 1980;2:159-162.

49 Fuss IJ, Marth $T$, Neurath MF, Pearistein GR, Jain A, Strober W: Antiminterleukin 12 treatment regulates apoptosis of Th1 T eells in experimental colitis in mice. Gastroenterology. 1999;117:1078-1088.

50 Matsuda S, Uchikawa R, Yamada M, Arizono $\mathrm{N}$ : Cytokine mRNA expression profiles in rats infected with the intestinal nematode Nippo strongylus brasiliensis. Infect Immun 1995;63: 4653-4660.

51 Fargeas MJ, Fioramonti J, Bueno L: Involve ment of capsaicin-sensitive afferent nerves in the intestinal motor alterations induced by testinal anaphylaxis in rats. Int Arch Allergy Immunol 1993;101:190-195.

52 Huang ZL, Mochizuki T, Watanabe $\mathrm{H}$, Maeya ma K: Activation of sensory nerves participates in stress-induced histamine release from mast cells in rats. Neurosci.Lett 1999;270,181-184,

53 Wallace JL, McKnight GW, Befus AD: Capsaicin-induced hyperemia in the stomach: Possibie contribution of mast cells. Am I Pliysiol 1992;263:G209-G214.

54 Dimitriadou V, Rouleau A, Trung Tuong MD Newiands GJ, Miller HR, Luffau G, Schwarty JC, Garbarg M: Füunctional relationships between sensory nerve fibers and mast cells of dura mater in normal and inflammatory condi. tions. Neuroscience 1997;77:829-839. 
$\mathrm{stan}$

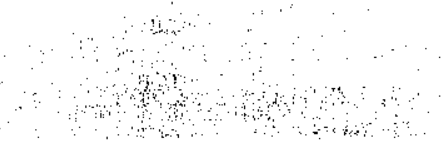

काल

and

and and

$\therefore$ का

$\therefore$

$\therefore \quad \therefore \quad \cdots$

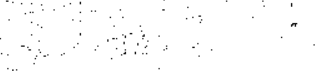

(a)

,

-

a dit?

(1)

$\therefore$

मीन

then

कीसम

m का 